\title{
Increased levels of HMGB1 and pro-inflammatory cytokines in children with febrile seizures
}

Jieun Choi ${ }^{*}$, Hyun Jin Min² and Jeon-Soo Shin ${ }^{2,3^{*}}$

\begin{abstract}
Objective: Febrile seizures are the most common form of childhood seizures. Fever is induced by proinflammatory cytokines during infection, and pro-inflammatory cytokines may trigger the development of febrile seizures. In order to determine whether active inflammation, including high mobility group box-1 (HMGB1) and pro-inflammatory cytokines, occurs in children with febrile seizures or epilepsy, we analyzed cytokine profiles of patients with febrile seizures or epilepsy.
\end{abstract}

Methods: Forty-one febrile seizure patients who visited the emergency department of Seoul National University Boramae Hospital from June 2008 to May 2009 were included in this study. Blood was obtained from the febrile seizure child patients within 30 minutes of the time of the seizure; subsequently, serum cytokine assays were performed. Control samples were collected from children with febrile illness without convulsion $(N=41)$ and similarly analyzed. Serum samples from afebrile status epilepticus attacks in intractable epilepsy children $(N=12)$, afebrile seizure attacks in generalized epilepsy with febrile seizure plus (GEFSP) children ( $N=6$ ), and afebrile nonepileptic controls $(N=7)$ were also analyzed.

Results: Serum HMGB1 and IL-1 $\beta$ levels were significantly higher in febrile seizure patients than in fever only controls $(p<0.05)$. Serum IL-6 levels were significantly higher in typical febrile seizures than in fever only controls $(p<0.05)$. Serum IL-1 $\beta$ levels were significantly higher in status epilepticus attacks in intractable epilepsy patients than in fever only controls $(p<0.05)$. Serum levels of IL-1 $\beta$ were significantly correlated with levels of HMGB1, IL-6, and TNF- $\alpha(p<0.05)$.

Conclusions: HMGB1 and pro-inflammatory cytokines were significantly higher in febrile seizure children. Although it is not possible to infer causality from descriptive human studies, our data suggest that HMGB1 and the cytokine network may contribute to the generation of febrile seizures in children. There may be a potential role for antiinflammatory therapy targeting cytokines and HMGB1 in preventing or limiting febrile seizures or subsequent epileptogenesis in the vulnerable, developing nervous system of children.

\section{Background}

Febrile seizures are the most common form of childhood seizures, occurring in $2 \%-5 \%$ of children younger than 6 years old [1]. Febrile seizures are defined as seizures that occur during a febrile state and without an obvious central nervous system infection. Fever is induced by pro-inflammatory cytokines such as interleukin (IL)-1 $\beta$, IL-6, and tumor necrosis factor (TNF)-

\footnotetext{
* Correspondence: jechoi66@snu.ac.kr; jsshin6203@yuhs.ac

'Department of Pediatrics, Seoul National University Boramae Hospital, Seoul National University, College of Medicine, Seoul, Korea

${ }^{2}$ Department of Microbiology, Yonsei University College of Medicine, Seoul, Korea

Full list of author information is available at the end of the article
}

$\alpha$ during infections. The fever threshold temperature for febrile seizures varies among individuals, as well as by age and maturation [2]. Genetic susceptibility to inflammation may influence the fever threshold temperature for febrile seizures, and $17-30 \%$ of febrile seizure patients have a family history of febrile seizures [2]. IL-1 $\beta$ biallelic polymorphism in the promoter region at the -511 position is significantly higher in febrile seizure patients than in fever only children, and this polymorphism results in an increase in IL- $1 \beta$ production $[3,4]$. However, others have failed to demonstrate a significant association between IL-1 $\beta(-511)$ and febrile seizures $[5,6]$. The association of IL-1 $\beta$ gene polymorphism and susceptibility to febrile

\section{() Biomed Central}


seizures is still controversial. Increased levels of IL-6, and IL-1-receptor antagonist/IL-1 $\beta$ ratio have been reported in the plasma of febrile seizure patients [3]. Viruses as causative agents of febrile seizures have been demonstrated in several reports. Neurotropic viruses, such as herpes and influenza A, are commonly associated with febrile seizures $[7,8]$.

Pro-inflammatory cytokines may trigger febrile seizures. In experimental animals, intraventricular injection of IL- $1 \beta$ reduces the seizure threshold in 14-day old mice subjected to hyperthermia, while IL- $1 \beta$ knock-out mice had an increased seizure threshold [9]. IL-1 $\beta$ increases glutamatergic neurotransmission and lowers the peak magnitude of GABA-mediated currents [10], supporting the role of pro-inflammatory cytokine contribution to the generation of fever-induced seizures [9]. Also, IL-1 $\beta$ prolongs the duration of electroencephalographic seizure [11].

High mobility group box-1 (HMGB1) has been shown to be a key mediator of inflammatory diseases. HMGB1 is a nuclear protein that triggers inflammation, binds to lipopolysaccharides (LPS) and IL-1, and initiates and synergizes with a Toll-like receptor (TLR) 4-mediated pro-inflammatory response [12]. After pro-inflammatory stimulation, such as that by LPS, TNF- $\alpha$, IL-1, IL- 6 and IL-8, HMGB1 is actively released from activated monocytes and macrophages. Regulation of HMGB1 secretion is important for control of HMGB1-mediated inflammation and is dependent on various processes such as phosphorylation by calcium-dependent protein kinase $\mathrm{C}$ [13], as well as acetylation and methylation [14]. In a recent study, HMGB1 and TLR4 were involved in the generation and recurrence of seizures in experimental animals $[15,16]$.

Cytokine analyses in our previous study showed that pro-inflammatory cytokine levels, including IL-1 $\beta$, IL-8, IL-12p70, and macrophage inflammatory protein (MIP)$1 \beta$, were significantly high in the epileptogenic cortex of intractable epilepsy children [17]. In addition, levels of IL-6 and MCP-1 were significantly high in patients with a family history of epilepsy. Active neuroinflammation, such as a marked activation of microglia and astrocytes as well as marked cellular injury, were also observed in epileptogenic brain tissue, supporting the suggestion that neuroinflammation may contribute to epileptogenesis in the developing brain.

In order to determine whether active inflammation, including HMGB1 and pro-inflammatory cytokines, occurs in children with febrile seizures and pediatric epilepsy, we analyzed cytokine profiles in the serum of child patients with febrile seizures or epilepsy and assessed the correlation between cytokine levels and febrile seizures.

\section{Materials and methods Patient information}

Forty-one febrile seizure patients who visited to emergency department of Seoul National University Boramae Hospital from June 2008 to May 2009 were included in this study (Table 1). Blood was obtained from patients within 30 minutes of the time of seizure, and serum was immediately separated and frozen for subsequent cytokine assay. Patient inclusion criteria were age between 6 months and 6 years, body temperature $\geq 38.5^{\circ} \mathrm{C}$, C-reactive protein $(\mathrm{CRP}) \leq 2.0$, and presented no other identifiable cause of the seizure. Clinical data for familial febrile seizure history, earlier febrile seizure attacks, as well as duration and semiology of febrile seizures were obtained from the patients' parents. Family history was regarded as positive when febrile seizures occurred in first-degree relatives. Laboratory findings, including complete blood counts $(\mathrm{CBC})$, blood chemistry, and CRP, were checked at the time of seizure. CRP levels higher than 2.0 were excluded due to presumptive presence of bacterial infection. Febrile seizure patients were classified into two types: typical type for whom febrile seizures persist for $<15$ minutes, are generalized tonicclonic, and only occur once within 24 hours; and atypical types for whom seizures persist for $>15$ minutes, or are partial seizures, or recur within 24 hours of the initial attack. Control samples were collected from children with febrile illness, but without convulsion $(\mathrm{N}=$ 41). Control groups were matched for age and temperature criteria and had no convulsions during the febrile illness and no known history of previous febrile seizures. Control blood serum was collected and frozen as above. In addition, blood serum was collected and frozen from afebrile status epilepticus attacks in intractable epilepsy children $(\mathrm{N}=12)$, afebrile seizure attacks in GEFSP children $(\mathrm{N}=6)$, and afebrile non-epileptic controls $(\mathrm{N}=7)$ for cytokine assay in order to subtract fever effects from the cytokine levels. The study was approved by the Institutional Review Board at the Seoul National University Boramae Medical Center (20080918/06-2008-74/76). Informed consent was obtained from each child's parents.

\section{Cytokine measurement}

Levels of pro-inflammatory cytokines including HMGB1, IL-1 $\beta$, IL-6, interferon (IFN)- $\beta$, TNF- $\alpha$, and anti-inflammatory cytokine IL-10 were measured using commercially available, enzyme-linked immunosorbent assay (ELISA) kits according to the manufacturer's instructions (for HMGB1, Shino-Test Corp., Tokyo, Japan [17]; for IL- $1 \beta$, IFN- $\beta$, TNF- $\alpha$, and IL-10, Panomics Inc., Redwood City, CA, USA; for IL-6, R\&D Systems, Minneapolis, MN, USA). Samples were analyzed in duplicate and 
Table 1 Clinical findings of febrile seizure, epilepsy, and control children

\begin{tabular}{|c|c|c|c|c|c|}
\hline & $\begin{array}{l}\text { Fever only control } \\
\qquad(N=41)\end{array}$ & $\begin{array}{l}\text { Febrile seizure } \\
\quad(\mathrm{N}=41)\end{array}$ & $\begin{array}{l}\text { Afebrile control } \\
\quad(\mathrm{N}=7)\end{array}$ & $\begin{array}{l}\text { Afebrile seizure } \\
\qquad(\mathrm{N}=6)\end{array}$ & $\begin{array}{c}\text { Afebrile } \\
\text { SE } \\
(N=12)\end{array}$ \\
\hline Age (year) & 3.1 & 2.1 & 7.9 & 7.6 & 6.3 \\
\hline Male/Female & $24 / 17$ & $29 / 12$ & $3 / 4$ & $4 / 2$ & $8 / 4$ \\
\hline BT at admission $\left({ }^{\circ} \mathrm{C}\right)$ & 38.4 & 39.0 & 36.6 & 37.0 & 36.5 \\
\hline $\begin{array}{l}\text { WBC count } \\
\left(\text { per } \mathrm{mm}^{3}\right)\end{array}$ & 11,719 & 12,068 & 7,540 & 8,716 & 9,560 \\
\hline CRP & 0.91 & 0.95 & 0.4 & 0.6 & 0.8 \\
\hline
\end{tabular}

$\mathrm{SE}$, status epilepticus; $\mathrm{BT}$, body temperature

compared with controls. The detection limits were 0.2 $\mathrm{ng} / \mathrm{mL}$ for HMGB1, $0.27 \mathrm{pg} / \mathrm{mL}$ for IL-1 $\beta, 0.23 \mathrm{pg} / \mathrm{mL}$ for IL-6, $0.21 \mathrm{pg} / \mathrm{mL}$ for IFN- $\gamma, 0.49 \mathrm{pg} / \mathrm{mL}$ for TNF- $\alpha$ and $0.22 \mathrm{pg} / \mathrm{mL}$ for IL-10.

\section{Statistical Analysis}

The $\chi^{2}$ test was used to compare the clinical characteristics between febrile seizure patients and the controls. The Mann-Whitney test was used to compare serum cytokine levels and laboratory findings between controls and febrile seizure patients. The Spearman's rank correlation coefficient was calculated to detect significant correlations between cytokine levels. The Kruskal Wallis test was used to compare cytokine levels among afebrile controls, febrile controls, and four seizure groups (first attack febrile seizure, recurrent attack febrile seizure, afebrile seizure attack in GEFSP, and afebrile status epilepticus attacks in intractable epilepsy patients). GraphPad Prism v. 4.0 (GraphPad Software Inc., San Diego, CA, USA) was used to perform the above tests. Values are expressed as means, and statistical significance of differences was set as $p<0.05$ for all tests.

\section{Results}

\section{Patient characteristics}

Table 1 summarizes the patient's clinical data. Fortyone febrile seizure patients and 41 control children with febrile illness without convulsion were included in this study. The mean age of febrile seizure patients was 2.1 years. Boys were more prevalent than girls

Table 2 Subgroups of febrile seizure patients

\begin{tabular}{lcc}
\hline & \multicolumn{2}{c}{ Febrile seizure patients $(\mathbf{N}=\mathbf{4 1})$} \\
\hline Family history of FS & Positive & $11(27 \%)$ \\
& Negative & $30(73 \%)$ \\
\hline FS history & First attack & $28(68 \%)$ \\
& Recurrent & $13(32 \%)$ \\
\hline FS type & Typical & $27(66 \%)$ \\
& Atypical & $14(34 \%)$ \\
\hline
\end{tabular}

FS, febrile seizure were (respectively, $71 \%$ vs. $29 \%$ ). Eleven (27\%) patients had a family history of febrile seizures and fourteen (34\%) patients exhibited atypical types of febrile seizures (Table 2). Twenty-eight patients (68\%) had their first febrile seizure attack and thirteen patients (32\%) had experienced previous febrile seizure attacks. Febrile seizure patients and febrile children without seizures did not significantly differ by sex, age, and laboratory data.

\section{Serum cytokine levels in the febrile seizure patients; increased IL-1 $\beta$, IL-6, IL-10 and HMGB levels}

In febrile seizure patients, serum IL- $1 \beta$ levels were at a 4-fold increase and HMGB1 levels were at a 1.3-fold increase higher than the fever only controls (Table 3, both $p<0.05)$. Serum levels of IL-6 were at a 1.8 -fold increase and IL-10 were at a 2.8 -fold increase in febrile seizure patients higher than the fever only controls, although statistically not significant (Table 3, $p=07$ and $p=0.05)$. There were no differences in serum IFN- $\gamma$ and TNF- $\alpha$ levels between febrile seizure patients and fever only controls (Table 3 ).

In comparisons of the subgroups of febrile seizure patients with the fever only control, typical febrile seizure patients showed a 4.2 -fold increase of IL-1 $\beta$ and a 1.9-fold increase of IL-6 levels higher than the fever only controls (Table 3 , both $p<0.05$ ). Both atypical febrile seizure and first attack febrile seizure patients showed a 1.5- and a 1.4-fold increase of HMGB1 levels higher than the fever only controls (Table 3 , both $p<$ $0.05)$. The IL-1 $\beta$ levels were at an 8.1 -fold increase in patients with recurrent febrile seizure attacks than those with first febrile seizure attack, although statistically not significant (Table $3, p=0.27$ ). IL-10 levels showed a 6.6-fold increase in children with recurrent febrile seizure attacks higher than the fever only controls (Table $3, p=0.06$ ). Febrile seizure patients without a family history of febrile seizures showed a 3.5fold increase of IL-10 levels (Table $3, p<0.05$ ) above the fever only controls and a 3.7-fold increase above those with FS without a family history of febrile seizures (Table $3, p=0.31$ ). 
Table 3 Comparisons of cytokine levels between fever only control and febrile seizure subgroups

\begin{tabular}{ccccccc}
\hline Groups (No.) & $\begin{array}{c}\mathrm{IL}-\mathbf{1} \boldsymbol{\beta} \\
(\mathbf{p g} / \mathbf{m L})\end{array}$ & $\begin{array}{c}\mathrm{IL}-\mathbf{6} \\
(\mathbf{p g} / \mathbf{m L})\end{array}$ & $\begin{array}{c}\text { HMGB1 } \\
(\mathbf{n g} / \mathbf{m L})\end{array}$ & $\begin{array}{c}\mathrm{IFN}-\boldsymbol{\gamma} \\
(\mathbf{p g} / \mathbf{m L})\end{array}$ & $\begin{array}{c}\text { TNF- } \boldsymbol{\alpha} \\
(\mathbf{p g} / \mathbf{m L})\end{array}$ & $\begin{array}{c}\mathrm{IL}-10 \\
(\mathbf{p g} / \mathbf{m L})\end{array}$ \\
\hline Fever only control (41) & $3.1 \pm 0.8+$ & $134.0 \pm 22.7$ & $24.8 \pm 2.5$ & $84.2 \pm 38.6$ & $5.6 \pm 2.9$ & $8.3 \pm 2.6$ \\
\hline Febrile seizures (41) & $12.0 \pm 5.3^{*}$ & $247.1 \pm 43.0$ & $32.6 \pm 3.0^{*}$ & $73.5 \pm 20.9$ & $5.0 \pm 1.8$ & $23.6 \pm 13.4$ \\
\hline Typical FS (27) & $12.9 \pm 7.6^{*}$ & $260.1 \pm 50.4^{*}$ & $30.5 \pm 3.8$ & $66.5 \pm 21.6$ & $3.0 \pm 0.9$ & $28.5 \pm 20.3$ \\
\hline Atypical FS (14) & $10.4 \pm 4.9$ & $228.3 \pm 81.2$ & $36.6 \pm 5.0^{*}$ & $86.9 \pm 45.9$ & $9.0 \pm 5.0$ & $14.2 \pm 3.8$ \\
\hline First FS (28) & $3.7 \pm 0.7$ & $252.7 \pm 53.5$ & $35.0 \pm 3.9^{*}$ & $74.6 \pm 21.3^{*}$ & $1.9 \pm 0.6$ & $9.2 \pm 2.2$ \\
\hline Recurrent FS (13) & $30.1 \pm 15.7$ & $241.7 \pm 73.0$ & $27.3 \pm 4.7$ & $70.9 \pm 48.8$ & $11.8 \pm 5.3$ & $54.6 \pm 41.8$ \\
\hline FS without FHx (30) & $13.0 \pm 6.9$ & $241.6 \pm 49.3$ & $31.8 \pm 3.6$ & $62.8 \pm 22.5$ & $5.2 \pm 2.4$ & $29.4 \pm 18.2^{*}$ \\
\hline FS with FHx (11) & $9.4 \pm 5.6$ & $270.1 \pm 89.2$ & $34.7 \pm 5.9$ & $102.6 \pm 48.5$ & $4.7 \pm 2.1$ & $7.8 \pm 2.7$ \\
\hline
\end{tabular}

* indicates a significant $(p<0.05)$ difference compared to fever only control (Mann-Whitney test).

FS, febrile seizure; FHx, family history; SE, status epilepticus

$\dagger$; mean \pm standard error of mean

\section{Serum cytokine levels in the afebrile control, febrile} control, and afebrile various seizure groups

\section{IL-1 $\beta$}

The mean IL-1 $\beta$ level of the afebrile control children was $2.0 \mathrm{pg} / \mathrm{mL}$, while that for the febrile control was 3.1 $\mathrm{pg} / \mathrm{mL}$. The mean IL-1 $\beta$ level in afebrile status epilepticus attacks in intractable epilepsy patients was at a 11.7fold increase higher than that of the afebrile controls ( 23.4 vs. $2.0 \mathrm{pg} / \mathrm{mL}$ ) and a 7.5-fold increase higher than of fever only controls (Table $3,23.4$ vs. $3.1 \mathrm{pg} / \mathrm{mL}, p<$ 0.05). Comparisons of IL-1 $\beta$ levels among afebrile and febrile controls and the four seizure groups (first and recurrent febrile seizures, afebrile seizures in GEFSP and afebrile status epilepticus in intractable epilepsy patients) showed significantly higher levels in the afebrile status epilepticus in intractable epilepsy and the recurrent febrile seizure groups (Figure $1 \mathrm{~A}, p<0.05$ ).

2. IL-6

The mean IL- 6 level of afebrile controls was $34.7 \mathrm{pg} /$ $\mathrm{mL}$, while that of febrile controls was $134.0 \mathrm{pg} / \mathrm{mL}$, and that of afebrile status epilepticus attacks in intractable epilepsy patients was $51.4 \mathrm{pg} / \mathrm{mL}$. Comparisons of IL-6 levels among afebrile and febrile controls, and the four seizure groups showed significantly higher IL-6 levels in first and recurrent attack febrile seizure patients (Figure $1 B, \mathrm{p}<0.05)$.

\section{3. $T N F-\alpha$}

The mean TNF- $\alpha$ level of afebrile controls was $3.4 \mathrm{pg} / \mathrm{mL}$, while that in febrile controls was $5.6 \mathrm{pg} / \mathrm{mL}$, and that in afebrile status epilepticus attacks in intractable epilepsy patients was $14.2 \mathrm{pg} / \mathrm{mL}$. Afebrile seizure patients showed a $57 \%$ decrease of TNF- $\alpha$ levels of febrile controls (Table $3, p<0.05)$. Comparisons of TNF- $\alpha$ levels among afebrile and febrile controls, and the four seizure groups showed higher levels in the afebrile status epilepticus attacks in intractable epilepsy patients and the recurrent attack febrile seizure groups (Figure $1 \mathrm{C}, \mathrm{p}=0.06$ ).

\section{HMGB1}

The mean HMGB1 level in the serum of afebrile controls was $9.0 \mathrm{ng} / \mathrm{mL}$, that in febrile control was $24.8 \mathrm{ng} /$ $\mathrm{mL}$, and that in afebrile status epilepticus attacks in intractable epilepsy patients was $30.1 \mathrm{ng} / \mathrm{mL}$. In comparisons of HMGB1 levels between afebrile controls, febrile controls and the four seizure groups, there were trends of higher HMGB1 levels in both febrile seizures and afebrile status epilepticus attacks in intractable epilepsy patients than in the febrile and afebrile controls, but this was not statistically significant (Figure $1 \mathrm{D}, \mathrm{p}=0.11$ ).

\section{IFN- $\gamma$}

The mean IFN- $\gamma$ level of afebrile controls was $20.8 \mathrm{pg} /$ $\mathrm{mL}$, that in febrile controls was $84.2 \mathrm{pg} / \mathrm{mL}$, and that in afebrile status epilepticus attacks in intractable epilepsy patients was $21.4 \mathrm{pg} / \mathrm{mL}$. Comparisons of IFN- $\gamma$ levels among afebrile and febrile controls, and the four seizure groups showed no significant differences (Table 3 ).

\section{IL-10}

The mean IL-10 level of afebrile controls was $2.7 \mathrm{pg} /$ $\mathrm{mL}$, that in febrile controls was $8.3 \mathrm{pg} / \mathrm{mL}$, and that in afebrile status epilepticus attacks in intractable epilepsy patients was $0.6 \mathrm{pg} / \mathrm{mL}$. Afebrile seizure patients and afebrile status epilepticus patients with intractable epilepsy showed significantly decreased IL-10 levels than that of febrile and afebrile controls $(2.6 \mathrm{pg} / \mathrm{mL} \& 0.6$ $\mathrm{pg} / \mathrm{mL}, p<0.05)$. There were no significant differences of IL-10 levels among afebrile controls, febrile controls and the four seizure groups (Table 3 ).

\section{The correlations between the various cytokines}

IL-1 $\beta$ serum levels were significantly correlated with HMGB1, IL-6, and TNF- $\alpha$ levels (respectively: Figures $2 \mathrm{~A}, \mathrm{~B}$, and $2 \mathrm{C} ; r=0.28, r=0.25$, and $r=0.45$; all $p<$ $0.05)$, but not with IL-10 and IFN- $\gamma$. Serum IL- 6 levels were significantly correlated with IL- $1 \beta$ and TNF- $\alpha$ levels (respectively: Figures 2B and 2D; $r=0.25$ and $r=$ 


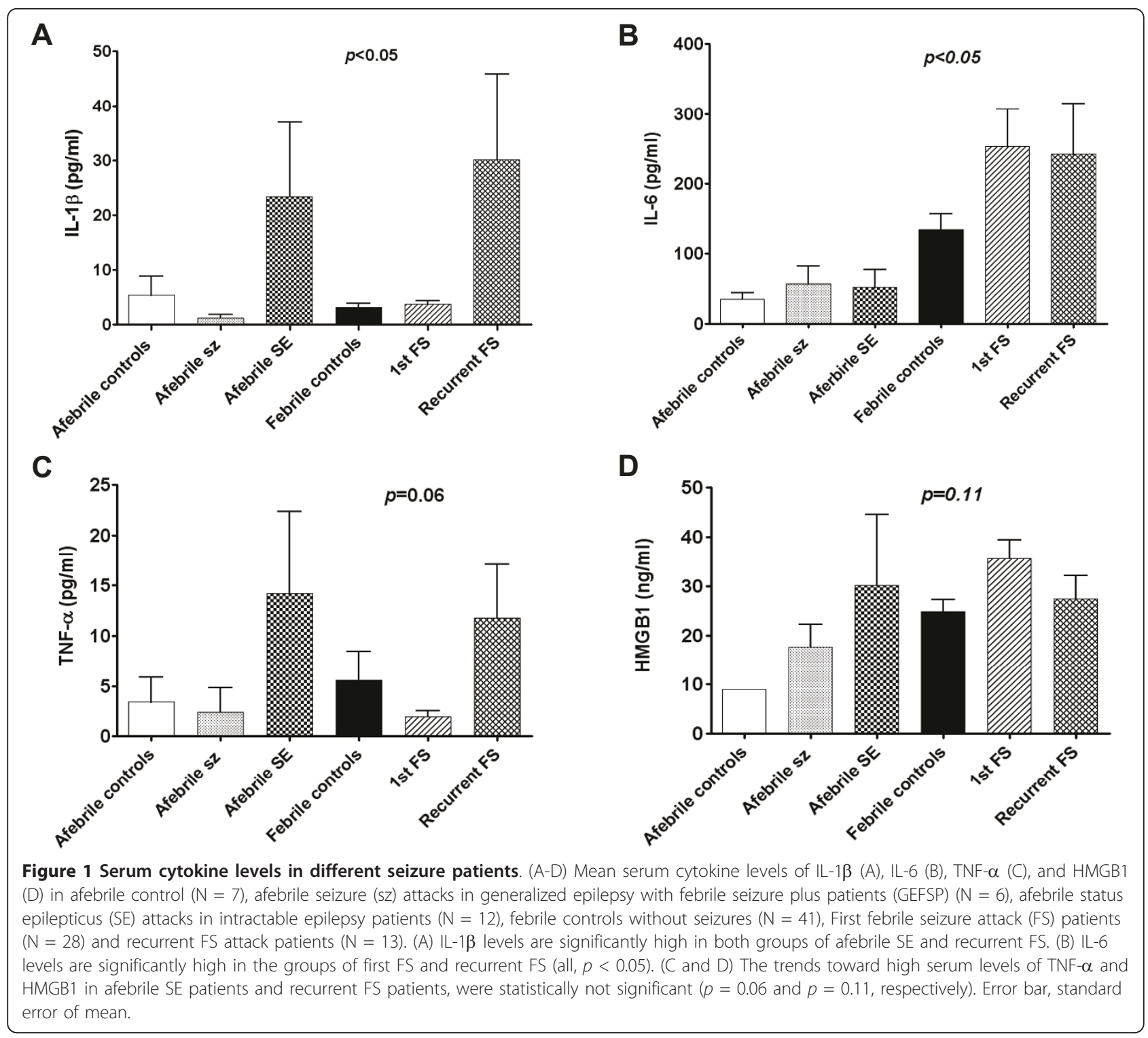

0.28 ; both $p<0.05)$, but were not correlated with HMGB1, IL-10, and IFN- $\gamma$ levels.

\section{Discussion}

This is the first study demonstrating a significant elevation of HMGB1 in the serum of febrile seizure patients. Moreover, serum levels of other pro-inflammatory cytokines, including IL- $1 \beta$, IL- 6 , and the antiinflammatory cytokine IL-10 were significantly higher among our patients with febrile seizures. IL- $1 \beta$ level increase was related to seizure recurrence and duration, as seen with the higher levels of IL- $1 \beta$ in recurrent febrile seizure or afebrile status epilepticus patients. In addition, IL-1 $\beta$ levels were significantly and positively correlated with HMGB1 levels and with other pro-inflammatory cytokines (IL- 6 and TNF- $\alpha$ ), supporting the association of the cytokine network in febrile seizures.

HMGB1 is a highly conserved, ubiquitously expressed protein [18] and is actively secreted from monocytes and macrophages in response to challenges with LPS [19]. HMGB1 binds to and transfers LPS, consequently increasing LPS-induced TNF- $\alpha$ production in human peripheral blood mononuclear cells [13]. HMGB1 is passively released from necrotic cells, but not from apoptotic cells, thereby creating a signal for the organism to distinguish between the two types of cell death [20]. Several clinical studies have reported that serum HMGB1 levels are elevated in patients with infection and/or systemic inflammatory response syndrome, than in healthy control individuals $[19,21]$. HMGB1 is involved in various diseases without obvious infections; 


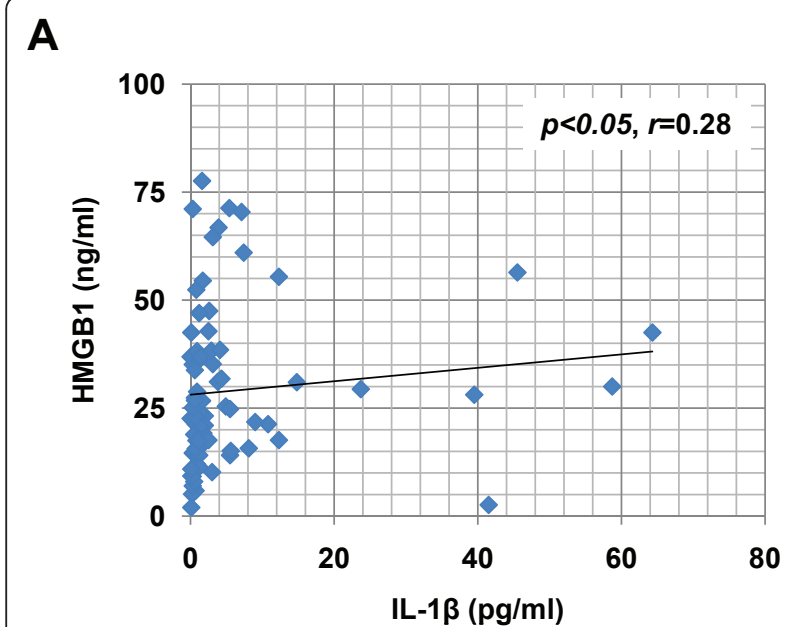

C

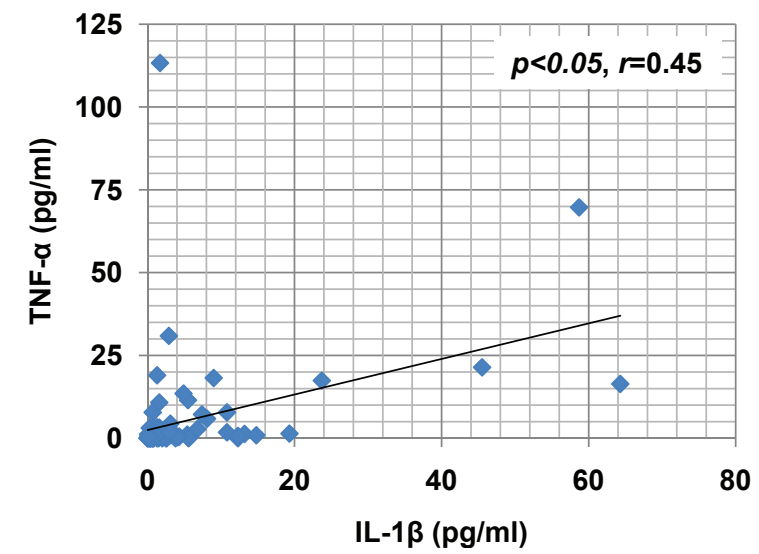

B

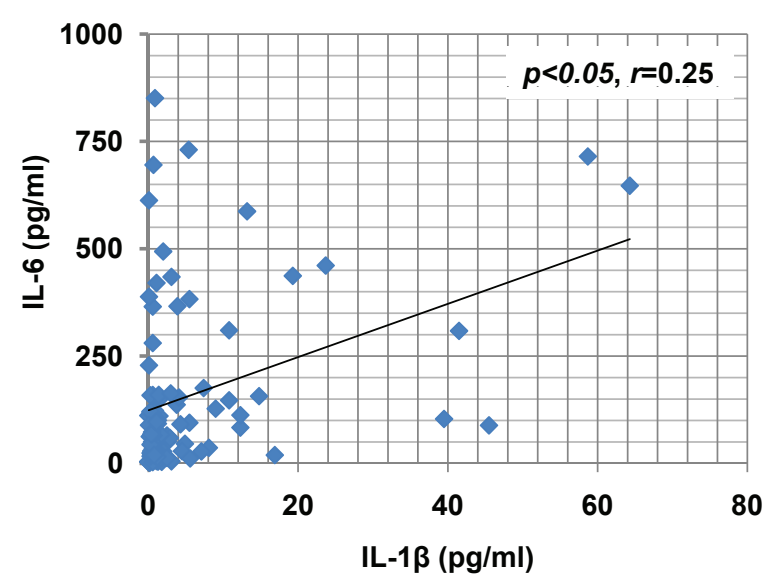

D

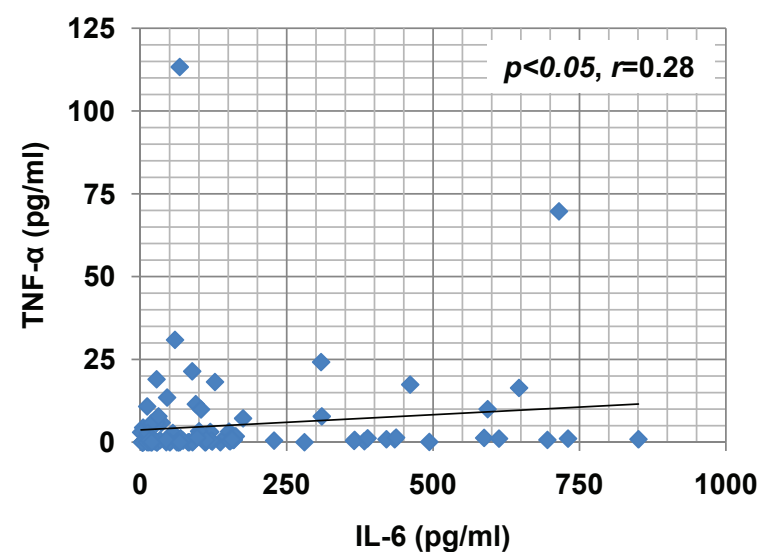

Figure 2 Correlation between serum cytokine levels in seizure patients. (A-D) Correlation between serum levels of IL-1 $\beta$ and $H M G B 1$ ( $1 \beta$ and IL-6 (B), IL-1 $\beta$ and TNF- $\alpha(C)$, and IL-6 and TNF- $\alpha(D)$ in febrile patients $(N=82)$. IL-1 $\beta$ levels are significantly correlated with HMGB1, IL-6, and TNF- $\alpha$ levels (all, $p<0.05, r=0.28,0.25$, and 0.45 , respectively). IL-6 levels are significantly correlated with TNF- $\alpha$ levels $(p<0.05, r=0.28$ ).

for example, rheumatoid arthritis [22], hemorrhagic shock [23], cerebral and myocardial ischemia [24], acute lung injury [25], and acute pancreatitis [26]. HMGB1 is highly expressed in human epileptogenic brain, and antagonists of HMGB1 and TLR4 have been demonstrated to retard seizure precipitation and to decrease acute and chronic seizure recurrence in epilepsy animals [15]. These findings suggest a role for the HMGB1TLR4 axis in epilepsy. In our study, serum levels of HMGB1 were significantly higher in febrile seizure patients and showed a positive correlation with IL-1 $\beta$ levels. Our results, together with those from other studies, suggest that HMGB1 activation is an important feature associated with epilepsy and febrile seizures.

IL-1 $\beta$ serum levels were significantly higher in our febrile seizures patients than in febrile children without seizures. IL-1 $\beta$ has been shown to have potent pro-convulsant properties in experimental animals [27]. IL-1 $\beta$ acts on astrocytes to increase glutamate release via
TNF- $\alpha$ production [28], resulting in elevated extracellular glutamate levels and hyper-excitability. Also, IL-1 $\beta$ can stimulate IL- 6 release [29]. In our patients, IL-1 $\beta$ levels were significantly correlated with IL-6, HMGB1, and TNF- $\alpha$ levels. In our previous work using epileptogenic brain cortices of children with intractable epilepsy, pro-inflammatory cytokines, IL-1 $\beta$, IL-8, IL-12p70, and MIP-1 $\beta$ were increased significantly above those in nonepileptogenic control brain cortices [30]. Our patients with intractable epilepsy experiencing status epilepticus attacks also showed high IL-1 $\beta$, IL- 6 and HMGB1 levels. These results together suggest that active inflammation does occur in febrile seizures and pediatric epilepsy, and it may play a common pathologic role in febrile seizures and epilepsy.

Since cytokine levels were measured with blood taken 30 min after the seizure, the acute effect of seizures could not be distinguished from a persistent inflammatory tone in febrile seizure patients. Seizures themselves 
can activate the sympathetic nervous system and induce the release of catecholamines [31,32], resulting in cytokine release from peripheral blood mononuclear cells [33]. However, in our study, patients with recurrent febrile seizure attacks had much higher IL- $1 \beta$ and TNF- $\alpha$ levels than patients with first attack febrile seizures, although interictal cytokine levels were not available after acute seizures. In animal models of prolonged febrile seizures, IL-1 $\beta$ was significantly high in the hippocampus for over 24 hours and was elevated chronically only in rats developing spontaneous limbic seizures after febrile status epilepticus $[9,34]$. These findings suggest that inflammatory responses in febrile seizures are accentuated by their repetition and increase the likelihood of febrile seizure recurrence.

Interestingly, no increase in serum IL-1 $\beta$ was detected in our children with fever but no seizures $(3.1 \mathrm{pg} / \mathrm{mL})$, as compared to controls without fever and with no seizures $(2.0 \mathrm{pg} / \mathrm{mL})$. In another study, similarly low IL- $1 \beta$ blood levels of $3.4 \mathrm{pg} / \mathrm{mL}$ were reported in the febrile control group [35]. This lack of increase may be the result of excluding patients with presumptive bacterial infections, because LPS is the main inducer for the synthesis of IL-1 $\beta$ [36]. Also, IL-1 $\beta$ is usually difficult to detect because of its binding to large proteins such as $\alpha-2$ macroglobulin and complement [37]. Furthermore, fever could occur independently of IL-1 or TNF activity during infections, and the cytokine-like property of TLR signal transduction could be one explanation [38].

The sources of the serum cytokine in febrile seizures patients are not clear. The main source of IL-1 is monocytes in the periphery and microglial cells in the nervous system, which upon activation secrete the cytokines. Cytokines are produced by astrocytes and some neurons in the CNS by LPS and other stimuli $[39,40]$. Under normal conditions, the levels of IL-1 are low, both in the circulation and in the CNS, whereas upon infection or injury, IL-1 levels increase abruptly but transiently, returning to normal within $8 \mathrm{~h}$ in healthy, young mouse brain [41]. Therefore, high serum levels of IL-1 $\beta$ may reflect high levels in the CNS. However, conflicting results about IL- $1 \beta$ levels have been reported in peripheral blood and CSF of children with febrile seizures, such as high in plasma but not in CSF [42], or high in CSF but not in serum [43] or increase in neither serum nor CSF [35]. These results potentially reflect difficulties in obtaining clinical samples and measuring free IL-1 $\beta$. The possible sources of the serum cytokine increases in febrile seizures may be peripheral mononuclear cells, CSF-blood exchange, and leakage from the brain reticuloendothelial system.

A dual role of IL- 6 in seizures has been demonstrated in several animal models. IL-6 knockout mice showed an increased seizure susceptibility to glutamate receptor agonists [44]. Transgenic mice over-expressing IL-6 in astrocytes were also reported to have an increased seizure susceptibility to glutamate receptor agonists, probably due to reduced GABA-mediated inhibition [45]. In developing rats, intra-nasal administration of IL-6 prolonged the latency and shortened the duration of hyperthermia-induced seizures, suggesting an anti-convulsant effect to febrile seizures [46]. On the other hand, intranasal administration of IL-6 in adult rats exacerbated the severity of seizures induced by pentylenetetrazole, supporting a pro-convulsant effect [47]. In our patients including only presumptive viral infections, serum IL-6 was higher in febrile seizure children than in fever only controls. Moreover, IL-6 levels in febrile seizure patients were much higher than in afebrile seizure attack patients. Higher IL- 6 and IFN- $\alpha$ levels have been reported in patients with influenza-associated febrile seizures compared to those without febrile seizures $[3,48]$. These findings, with our results, may support the proconvulsant action of IL-6 in febrile seizures.

IL-10 is a multifunctional anti-inflammatory cytokine produced by monocytes, macrophages, lymphocytes, as well as microglia and inhibits the production of proinflammatory cytokines, including IL-1, IL-6, IL-8, and TNF- $\alpha$ [49]. Peripheral blood mononuclear cells from febrile seizure patients have shown increased IL-10 production by LPS [50]. In IL-10 injected animals, the febrile seizure threshold was significantly higher than that in controls, suggesting that IL-10 is associated with a resistance to febrile seizures [51]. Previously, plasma IL10 levels showed no difference between febrile seizures and controls [3]. However, in our patients, IL-10 levels were higher in recurrent febrile seizure patients than in first attack febrile seizure patients and were also higher in patients without a family history of febrile seizures than in patients with family history. These findings may reflect compensatory activation of anti-inflammatory or anti-convulsive mechanisms, or mechanism defects in the anti-inflammatory role of IL-10 in febrile seizure families; further studies into the role of IL-10 are warranted.

TNF- $\alpha$ causes both detrimental and beneficial effects on brain function depending on its concentration, targeted cells, duration of exposure and the specific receptor subtypes [52,53]. TNF- $\alpha$ is rapidly upregulated in the CNS by seizures, and intrahippocampal injection of TNF- $\alpha$ potently inhibit seizure in a mice model of epilepsy [54]. In our children with acute and brief seizures, either febrile or afebrile, serum TNF- $\alpha$ was decreased, or at least not increased, supporting that TNF- $\alpha$ is not involved in the mechanisms by which seizures are triggered. On the other hand, transgenic mice over-expressing high amounts of TNF- $\alpha$ in astrocytes developed spontaneous seizures, [55] and TNF- $\alpha$ has been shown 
to increase excitatory postsynaptic currents in hippocampal neurons [56] and to decrease $\mathrm{GABA}_{\mathrm{A}}$-mediated inhibitory synaptic strength, leading to increased seizure susceptibility $[57,58]$. Our recurrent febrile seizure patients showed higher serum TNF- $\alpha$ levels than first attack febrile seizure patients, and afebrile status epilepticus attacks in intractable epilepsy patients showed higher serum TNF- $\alpha$ level than short-duration seizure attacks in GEFSP patients, supporting that chronic or recurrent expression of TNF- $\alpha$ may change susceptibility to seizures.

The causative role of cytokines in epileptogenesis remains to be elucidated. Cytokines may contribute initially to incite seizures in the developing brain after being induced by seizure or tissue injury, and they may exacerbate tissue injury and promote further seizures. Furthermore, cytokine gene polymorphisms have been linked to epilepsy susceptibility [4]. Thus, it may be worthwhile to explore further a possible link between febrile seizures and genetic susceptibility to inflammation.

In summary, HMGB1 and pro-inflammatory cytokines were significantly higher in febrile seizure patients. Although it is not possible to infer causality from descriptive human studies, our data suggest that HMGB1 and the cytokine network may contribute to the generation of febrile seizures in children. Proinflammatory cytokine production may promote seizures, further exacerbate epilepsy, and may cause subsequent intractable epilepsy. If so, there may be a potential role for anti-inflammatory therapy targeting cytokines and HMGB1 as a novel therapeutic strategy to prevent or limit febrile seizures or subsequent epileptogenesis in the vulnerable, developing nervous system of children.

\section{Acknowledgements}

This research was supported by the Basic Science Research Program through the National Research Foundation of Korea funded by the Ministry of Education, Science and Technology (800-20110174), the Seoul National University Hospital Research Fund (04-2008-0960), and the Seoul National University Boramae Hospital Research Fund (03-2011-15) to JC, and by the Mid-Career Researcher Program (2009-0081001), NRF (2011-0017611), and the second stage BK21 for Medical Sciences of Yonsei University to JS.

\section{Author details}

'Department of Pediatrics, Seoul National University Boramae Hospital, Seoul National University, College of Medicine, Seoul, Korea. ${ }^{2}$ Department of Microbiology, Yonsei University College of Medicine, Seoul, Korea. ${ }^{3}$ Severance Biomedical Science Institute and Institute for Immunology and Immunological Diseases, Yonsei University College of Medicine, Seoul, Korea.

\section{Authors' contributions}

$J C$ reviewed and helped in analyzing data, obtained IRB approval and permissions from the patients and their parents, processed serum from the patients, conducted cytokine analyses, and helped draft and prepare the manuscript for publication. HM performed the HMGB1 ELISA analyses. JS reviewed and helped in the data analyses as well as helped with drafting and preparing the manuscript for publication. All authors have read and approved the final version of the manuscript.

\section{Competing interests}

The authors declare that they have no competing interests.

Received: 5 August 2011 Accepted: 11 October 2011

Published: 11 October 2011

\section{References}

1. Hauser WA: The prevalence and incidence of convulsive disorders in children. Epilepsia 1994, 35(Suppl 2):S1-6.

2. Millichap JG: Studies in febrile seizures. I. Height of body temperature as a measure of the febrile-seizure threshold. Pediatrics 1959, 23:76-85.

3. Virta $M$, Hurme $M$, Helminen $M$ : Increased frequency of interleukin-1beta (-511) allele 2 in febrile seizures. Pediatr Neurol 2002, 26:192-195.

4. Kanemoto K, Kawasaki J, Yuasa S, Kumaki T, Tomohiro O, Kaji R, Nishimura M: Increased frequency of interleukin-1beta-511T allele in patients with temporal lobe epilepsy, hippocampal sclerosis, and prolonged febrile convulsion. Epilepsia 2003, 44:796-799.

5. Tilgen N, Pfeiffer H, Cobilanschi J, Rau B, Horvath S, Elger CE, Propping P, Heils A: Association analysis between the human interleukin 1 beta $(-511)$ gene polymorphism and susceptibility to febrile convulsions. Neurosci Lett 2002, 334:68-70.

6. Chou IC, Lin WD, Wang CH, Tsai CH, Li TC, Tsai FJ: Interleukin (IL)-1beta, IL1 receptor antagonist, IL-6, IL-8, IL-10, and tumor necrosis factor alpha gene polymorphisms in patients with febrile seizures. Journal of clinical laboratory analysis 2010, 24:154-159.

7. Hall CB, Long CE, Schnabel KC, Caserta MT, Mclntyre KM, Costanzo MA, Knott A, Dewhurst S, Insel RA, Epstein LG: Human herpesvirus-6 infection in children. A prospective study of complications and reactivation. $N$ Engl J Med 1994, 331:432-438.

8. Chiu SS, Tse CY, Lau YL, Peiris M: Influenza A infection is an important cause of febrile seizures. Pediatrics 2001, 108:E63.

9. Dube C, Vezzani A, Behrens M, Bartfai T, Baram TZ: Interleukin-1beta contributes to the generation of experimental febrile seizures. Annals of neurology 2005, 57:152-155.

10. Wang S, Cheng Q, Malik S, Yang J: Interleukin-1beta inhibits gammaaminobutyric acid type $A(G A B A(A))$ receptor current in cultured hippocampal neurons. J Pharmacol Exp Ther 2000, 292:497-504

11. Vezzani A, Conti M, De Luigi A, Ravizza T, Moneta D, Marchesi F, De Simoni MG: Interleukin-1beta immunoreactivity and microglia are enhanced in the rat hippocampus by focal kainate application: functional evidence for enhancement of electrographic seizures. J Neurosci 1999, 19:5054-5065.

12. Youn JH, Oh YJ, Kim ES, Choi JE, Shin JS: High Mobility Group Box 1 Protein Binding to Lipopolysaccharide Facilitates Transfer of Lipopolysaccharide to CD14 and Enhances Lipopolysaccharide-Mediated TNF-\{alpha\} Production in Human Monocytes. J Immunol 2008, 180:5067-5074

13. Oh YJ, Youn JH, Ji Y, Lee SE, Lim KJ, Choi JE, Shin JS: HMGB1 is phosphorylated by classical protein kinase $C$ and is secreted by a calcium-dependent mechanism. J Immunol 2009, 182:5800-5809.

14. Rauvala $H$, Rouhiainen A: Physiological and pathophysiological outcomes of the interactions of HMGB1 with cell surface receptors. Biochim Biophys Acta 2010, 1799:164-170.

15. Maroso M, Balosso S, Ravizza T, Liu J, Aronica E, lyer AM, Rossetti C, Molteni M, Casalgrandi M, Manfredi AA, et al: Toll-like receptor 4 and high-mobility group box-1 are involved in ictogenesis and can be targeted to reduce seizures. Nat Med 2010, 16:413-419.

16. Vezzani A, French J, Bartfai T, Baram TZ: The role of inflammation in epilepsy. Nat Rev Neurol 2011, 7:31-40.

17. Yamada S, Inoue K, Yakabe K, Imaizumi H, Maruyama I: High mobility group protein 1 (HMGB1) quantified by ELISA with a monoclonal antibody that does not cross-react with HMGB2. Clin Chem 2003, 49:1535-1537.

18. Muller S, Ronfani L, Bianchi ME: Regulated expression and subcellular localization of HMGB1, a chromatin protein with a cytokine function. J Intern Med 2004, 255:332-343.

19. Wang $H$, Bloom $O$, Zhang M, Vishnubhakat JM, Ombrellino M, Che J, Frazier A, Yang H, Ivanova S, Borovikova L, et al: HMG-1 as a late mediator of endotoxin lethality in mice. Science 1999, 285:248-251.

20. Scaffidi P, Misteli T, Bianchi ME: Release of chromatin protein HMGB1 by necrotic cells triggers inflammation. Nature 2002, 418:191-195. 
21. van Zoelen MA, Laterre PF, van Veen SQ, van Till JW, Wittebole X, Bresser P, Tanck MW, Dugernier T, Ishizaka A, Boermeester MA, van der Poll T: Systemic and local high mobility group box 1 concentrations during severe infection. Crit Care Med 2007, 35:2799-2804.

22. Taniguchi N, Kawahara K, Yone K, Hashiguchi T, Yamakuchi M, Goto M, Inoue K, Yamada S, ljiri K, Matsunaga S, et al: High mobility group box chromosomal protein 1 plays a role in the pathogenesis of rheumatoid arthritis as a novel cytokine. Arthritis Rheum 2003, 48:971-981.

23. Ombrellino M, Wang H, Ajemian MS, Talhouk A, Scher LA, Friedman SG, Tracey KJ: Increased serum concentrations of high-mobility-group protein 1 in haemorrhagic shock. Lancet 1999, 354:1446-1447.

24. Goldstein RS, Gallowitsch-Puerta M, Yang L, Rosas-Ballina M, Huston JM, Czura CJ, Lee DC, Ward MF, Bruchfeld AN, Wang H, et al: Elevated highmobility group box 1 levels in patients with cerebral and myocardial ischemia. Shock (Augusta, Ga) 2006, 25:571-574.

25. Ueno H, Matsuda T, Hashimoto S, Amaya F, Kitamura Y, Tanaka M, Kobayashi A, Maruyama I, Yamada S, Hasegawa N, et al: Contributions of high mobility group box protein in experimental and clinical acute lung injury. Am J Respir Crit Care Med 2004, 170:1310-1316.

26. Yasuda T, Ueda T, Takeyama Y, Shinzeki M, Sawa H, Nakajima T, Ajiki T, Fujino $Y$, Suzuki $Y$, Kuroda $Y$ : Significant increase of serum high-mobility group box chromosomal protein 1 levels in patients with severe acute pancreatitis. Pancreas 2006, 33:359-363.

27. Balosso S, Maroso M, Sanchez-Alavez M, Ravizza T, Frasca A, Bartfai T, Vezzani A: A novel non-transcriptional pathway mediates the proconvulsive effects of interleukin-1beta. Brain 2008, 131:3256-3265.

28. Bezzi $P$, Volterra A: A neuron-glia signalling network in the active brain. Current opinion in neurobiology 2001, 11:387-394.

29. Aronica E, Gorter JA, Redeker S, Ramkema M, Spliet WG, van Rijen PC, Leenstra S, Troost D: Distribution, characterization and clinical significance of microglia in glioneuronal tumours from patients with chronic intractable epilepsy. Neuropathol Appl Neurobiol 2005, 31:280-291.

30. Choi J, Nordli DR Jr, Alden TD, DiPatri A Jr, Laux L, Kelley K, Rosenow J, Schuele SU, Rajaram V, Koh S: Cellular injury and neuroinflammation in children with chronic intractable epilepsy. J Neuroinflammation 2009, 6:38.

31. Rosenbaum KJ, Sapthavichaikul S, Skovsted P: Sympathetic nervous system response to lidocaine induced seizures in cats. Acta Anaesthesiol Scand 1978, 22:548-555.

32. Sakamoto K, Saito T, Orman R, Koizumi K, Lazar J, Salciccioli L, Stewart M: Autonomic consequences of kainic acid-induced limbic cortical seizures in rats: peripheral autonomic nerve activity, acute cardiovascular changes, and death. Epilepsia 2008, 49:982-996.

33. Meisel C, Schwab JM, Prass K, Meisel A, Dirnagl U: Central nervous system injury-induced immune deficiency syndrome. Nat Rev Neurosci 2005, 6:775-786.

34. Dube CM, Ravizza T, Hamamura M, Zha Q, Keebaugh A, Fok K, Andres AL, Nalcioglu O, Obenaus A, Vezzani A, Baram TZ: Epileptogenesis provoked by prolonged experimental febrile seizures: mechanisms and biomarkers. J Neurosci 2010, 30:7484-7494.

35. Lahat E, Livne M, Barr J, Katz Y: Interleukin-1 beta levels in serum and cerebrospinal fluid of children with febrile seizures. Pediatr Neurol 1997, 17:34-36.

36. Dantzer R, Bluthe RM, Gheusi G, Cremona S, Laye S, Parnet P, Kelley KW: Molecular basis of sickness behavior. Ann N Y Acad Sci 1998, 856:132-138.

37. Dinarello CA: Biologic basis for interleukin-1 in disease. Blood 1996, 87:2095-2147.

38. Dinarello CA: Infection, fever, and exogenous and endogenous pyrogens: some concepts have changed. J Endotoxin Res 2004, 10:201-222.

39. van Dam AM, Poole S, Schultzberg M, Zavala F, Tilders FJ: Effects of peripheral administration of LPS on the expression of immunoreactive interleukin-1 alpha, beta, and receptor antagonist in rat brain. Ann N Y Acad Sci 1998, 840:128-138.

40. Eriksson C, Tehranian R, Iverfeldt K, Winblad B, Schultzberg M: Increased expression of mRNA encoding interleukin-1beta and caspase-1, and the secreted isoform of interleukin-1 receptor antagonist in the rat brain following systemic kainic acid administration. J Neurosci Res 2000, 60:266-279.

41. Rooker S, Jander S, Van Reempts J, Stoll G, Jorens PG, Borgers M, Verlooy J: Spatiotemporal pattern of neuroinflammation after impact-acceleration closed head injury in the rat. Mediators Inflamm 2006, 2006:90123.
42. Tutuncuoglu S, Kutukculer N, Kepe L, Coker C, Berdeli A, Tekgul H: Proinflammatory cytokines, prostaglandins and zinc in febrile convulsions. Pediatr Int 2001, 43:235-239.

43. Haspolat S, Mihci E, Coskun M, Gumuslu S, Ozben T, Yegin O: Interleukin1 beta, tumor necrosis factor-alpha, and nitrite levels in febrile seizures. $J$ Child Neurol 2002, 17:749-751.

44. De Sarro G, Russo E, Ferreri G, Giuseppe B, Flocco MA, Di Paola ED, De Sarro A: Seizure susceptibility to various convulsant stimuli of knockout interleukin-6 mice. Pharmacology, biochemistry, and behavior 2004, 77:761-766.

45. Samland H, Huitron-Resendiz S, Masliah E, Criado J, Henriksen SJ, Campbell IL: Profound increase in sensitivity to glutamatergic- but not cholinergic agonist-induced seizures in transgenic mice with astrocyte production of IL-6. J Neurosci Res 2003, 73:176-187.

46. Furukawa K, Mattson MP: The transcription factor NF-kappaB mediates increases in calcium currents and decreases in NMDA- and AMPA/ kainate-induced currents induced by tumor necrosis factor-alpha in hippocampal neurons. J Neurochem 1998, 70:1876-1886.

47. Kalueff AV, Lehtimaki KA, Ylinen A, Honkaniemi J, Peltola J: Intranasal administration of human IL- 6 increases the severity of chemically induced seizures in rats. Neurosci Lett 2004, 365:106-110.

48. Masuyama T, Matsuo M, Ichimaru T, Ishii K, Tsuchiya K, Hamasaki Y: Possible contribution of interferon-alpha to febrile seizures in influenza. Pediatr Neurol 2002, 27:289-292.

49. Williams K, Dooley N, Ulvestad E, Becher B, Antel JP: IL-10 production by adult human derived microglial cells. Neurochem Int 1996, 29:55-64.

50. Straussberg R, Amir J, Harel L, Punsky I, Bessler H: Pro- and antiinflammatory cytokines in children with febrile convulsions. Pediatr Neurol 2001, 24:49-53.

51. Ishizaki Y, Kira R, Fukuda M, Torisu H, Sakai Y, Sanefuji M, Yukaya N, Hara T: Interleukin-10 is associated with resistance to febrile seizures: genetic association and experimental animal studies. Epilepsia 2009, 50:761-767.

52. Gary DS, Bruce-Keller AJ, Kindy MS, Mattson MP: Ischemic and excitotoxic brain injury is enhanced in mice lacking the p55 tumor necrosis factor receptor. J Cereb Blood Flow Metab 1998, 18:1283-1287.

53. Bruce AJ, Boling W, Kindy MS, Peschon J, Kraemer PJ, Carpenter MK, Holtsberg FW, Mattson MP: Altered neuronal and microglial responses to excitotoxic and ischemic brain injury in mice lacking TNF receptors. Nat Med 1996, 2:788-794.

54. Balosso S, Ravizza T, Perego C, Peschon J, Campbell IL, De Simoni MG, Vezzani A: Tumor necrosis factor-alpha inhibits seizures in mice via p75 receptors. Ann Neurol 2005, 57:804-812.

55. Akassoglou K, Probert L, Kontogeorgos G, Kollias G: Astrocyte-specific but not neuron-specific transmembrane TNF triggers inflammation and degeneration in the central nervous system of transgenic mice. $J$ Immunol 1997, 158:438-445.

56. Wheeler D, Knapp E, Bandaru W, Wang Y, Knorr D, Poirier C, Mattson MP, Geiger JD, Haughey NJ: Tumor necrosis factor-alpha-induced neutral sphingomyelinase- 2 modulates synaptic plasticity by controlling the membrane insertion of NMDA receptors. J Neurochem 2009, 109:1237-1249.

57. Beattie EC, Stellwagen D, Morishita W, Bresnahan JC, Ha BK, Von Zastrow M, Beattie MS, Malenka RC: Control of synaptic strength by glial TNFalpha. Science 2002, 295:2282-2285.

58. Stellwagen D, Beattie EC, Seo JY, Malenka RC: Differential regulation of AMPA receptor and GABA receptor trafficking by tumor necrosis factoralpha. J Neurosci 2005, 25:3219-3228.

doi:10.1186/1742-2094-8-135

Cite this article as: Choi et al:: Increased levels of HMGB1 and proinflammatory cytokines in children with febrile seizures. Journal of Neuroinflammation 2011 8:135. 